\title{
Air Travel-Associated Venous Thromboembolism
}

\author{
Omer Iqbala Bo Eklof ${ }^{b}$ Mahmut Tobu ${ }^{a}$ J awed Fareed ${ }^{a}$ \\ aLoyola University Medical Center, Maywood, IIl., and bUniversity of Hawaii, Honolulu, Hawaii, USA
}

\section{Key Words}

Thromboembolism . Protein C. Thrombophilia .

Mutation · Prothrombin · Hypoxia

\begin{abstract}
Long-distance air travel is increasing and cases of venous thromboembolism (VTE) following air travel have attracted both considerable public attention and legal claims against airlines. VTE is a common disorder worldwide with a notably high incidence in older individuals. Many biochemical factors that lead to, or accentuate, thrombus formation are associated with increased risk of VTE. These factors include thrombophilia, activated protein $C$ resistance and factor $V$ Leiden, prothrombin gene mutation, antiphospholipid antibodies, protein $\mathrm{S}$ and protein $\mathrm{C}$ deficiencies, and methylene tetrahydrofolate reductase polymorphism and homocysteinemia. Individual physical characteristics including age, weight and height are significant for personal risk of VTE as are other factors such as use of oral contraceptives in women. In the case of air travel-related venous thrombosis, superimposed upon these individual factors are the environmental factors directly related to air travel. Travel-related factors include stasis associated with prolonged periods of immobility, physiological stresses resulting from ex-
\end{abstract}

posure to the cabin environment (low humidity and hypoxia) in long-haul flight and other in-flight factors. It is suggested that passenger behavior (movement, avoidance of dehydration and of alcohol) and appropriate pharmacological prophylaxis for high-risk travelers can reduce the likelihood of VTE. Physical prophylaxis (use of compression stockings or in-flight exercise devices) may also be of general benefit to passengers. It is recommended that airlines become more proactive in educating passengers concerning the dangers of VTE and in promoting passenger actions that can reduce risk. Airlines should also work to avoid cramped seating conditions (seat size and pitch) that contribute to prolonged immobility. Governments and regulatory authorities should mandate the provision of adequate seating conditions and a good cabin environment and should support studies that will define risks and determine the efficacy of protocols to minimize dangers of VTE. Increased longhaul air traffic and an aging population suggest that travel-related VTE may present a growing healthcare threat and has highlighted a need for additional biomedical research into the causes and potential solutions to this problem.

Copyright $\odot 2003$ S. Karger AG, Base

\section{KARGER \\ Fax +41613061234 \\ E-Mail karger@karger.ch \\ www.karger.com

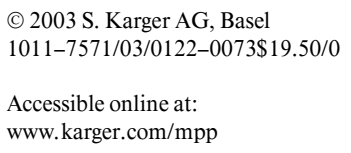

Omer Iqbal, MD

Department of Pathology, Loyola University Medical Center

2160 S. First Avenue, Building 102, Room 2646

Maywood, IL 60153 (USA)

Tel. +1 7082166807, Fax +1 708216 6660, E-Mail oiqbal@lumc.edu 


\section{Introduction}

Venous thromboembolism (VTE) is a common disorder worldwide. The estimated annual incidence of symptomatic thromboembolism is 117 cases per 100,000 people [1] or more than 250,000 patients each year in the United States. The incidence is age-dependent, increasing from zero in children to less than 1 per 10,000 in young adults and 3-5 per 10,000 in individuals over the age of 60 with additional increments with each additional decade [2]. With a large proportion of the US population entering the older age-group, VTE will become an increasingly important national health problem [1]. Venous thrombosis commonly develops in the deep veins of the leg (calf-vein thrombosis and proximal-vein thrombosis involving the popliteal, femoral or iliac veins) or the arm. Pulmonary emboli are sequelae from thrombi in the deep veins of the leg in $90 \%$ or more patients. Deep-vein thrombosis (DVT) and/or pulmonary embolism are referred to as VTE. Rudolf Virchow [3] was the first to recognize that VTE may be precipitated by venous stasis secondary to immobility.

Homans [4] first described in 1954 the possible association between long-distance air travel and VTE and reported 5 cases of DVT after prolonged sitting. He also described the association between car travel and VTE. Later, Symington and Stack [5] also reported thromboembolic events following long-distance travel and referred to the problem as 'economy class syndrome' [5]. Reports of pulmonary embolism as a second leading cause of travelrelated deaths at London's Heathrow airport [6] raised much concern and resulted in a series of reports linking prolonged air travel and VTE [7-12]. With the increase in international air traffic, VTE following long-distance travel has been widely recognized and further documented in the literature; Ferrari et al. [9] reported that long-distance travel was associated with an increased risk for thromboembolic disease. Samama [13] reported an epidemiologic study of risk factors for DVT in medical outpatients. Kraajenhagen et al. [14] reported on travel and risk of venous thrombosis. In this study, the number of events and subjects exposed to long-distance travel were small and could not confirm an association between air travel and VTE. Scurr et al. [15] reported on the results of a randomized trial on the frequency and prevention of symptomless DVT and long-haul flights. The results of biased ultrasonographic assessments were questioned [15]. Belcaro et al. [16] published on venous thromboembolism from air travel - the LONFLIT study. In the LONFLIT 1 study, 355 patients at low risk for DVT and
389 patients at high risk were studied. After a 12.4-hour economy class flight, no events were recorded in the lowrisk group but in the high-risk group, 11 patients had DVT (2.8\%). In the LONFLIT 2 study, of the 833 subjects, 422 were randomized as control subjects and 411 used below-knee stockings as a prophylactic measure against VTE. Parsi et al. [17] reported on 'Traveller's venous thromboembolism', a review of the world literature which encompassed a survey of the world airlines and presented an Australian perspective. Lapostolle et al. [18] reported on severe pulmonary embolism associated with air travel, recording 56 cases in 135.3 million passengers passing Charles de Gaulle airport in France. The frequency of embolism in long-haul passengers $(>5,000 \mathrm{~km})$ was 150 times higher than the incidence in passengers traveling shorter distances. Kline et al. [19] reported that the incidence of fatal pulmonary embolism immediately after transatlantic air travel to the United States was less than 1 in a million.

Press reports of 'economy class syndrome' have not only attracted public attention but have created tremendous anxiety in the minds of airline officials. Many lawsuits have been filed against the industry concerning their failure to warn passengers of the potential health risks, including VTE, of long-distance air travel.

\section{An International Consensus View of VTE and Air Travel}

Alerted by the media, the World Health Organization (WHO) recently convened a meeting of experts (WHO Consultation Meeting, Geneva, Switzerland, March 12 13, 2001, Chairman: Dr. F. Peccaud, Lausanne) with the intention to: (a) review and synthesize the information on air travel-related venous thrombosis (ATVT); (b) define the extent of the problem; (c) identify priority areas of research to find possible solutions if a problem exists, and (d) try to reach a consensus of pragmatic strategies for prevention based on currently available evidence [20].

The experts agreed: (a) that an association probably exists between air travel and venous thrombosis; (b) such an association is likely to be small and mainly affects passengers with additional risk factors for venous thromboembolism; (c) similar links may exist for other forms of travel; (d) available evidence does not permit an estimation of actual risk, and therefore public health recommendations cannot be made at the present time.

The representatives of the airlines agreed that: (a) an association between venous thrombosis and travel in general probably exists; (b) there are insufficient data on which to make recommendations; (c) airlines and the 
International Air Transport Association (IATA) are consequently committed to support further research.

It was the unanimous view of the participants that these studies should be undertaken as soon as possible under the auspices of WHO and supported by an independent scientific committee in close collaboration with IATA and International Civil Aviation Organization (ICAO). The priorities for research were suggested in three areas and protocols for funding were drawn up:

(1) A set of multicenter, international, epidemiological studies including a large prospective cohort study examining hard clinical endpoints to answer the following questions: Is there an association and if so, what is the absolute risk? What is the size of the problem? Studies on aircrew and cabin staff, as well as populations from multinational companies are planned.

(2) A set of special small-scale studies seeking intermediate endpoints and/or specific questions to groups of volunteers examining isolated independent environmental and behavioral risk factors. These studies will include physiopathological studies using hypobaric chambers.

(3) A set of interventional studies to assess preventive measures on the occurrence of ATVT with standardized diagnostic methods, involving passengers in experimental well-controlled studies.

\section{Venous Thrombosis: Factors Contributing to Thrombosis Risks}

\section{Individual Factors}

The pathogenesis of DVT as proposed by Virchow [3] is based on three groups of factors ('Virchow's triad'), namely, hypercoagulability, stasis and venous injury. More than one personal risk factor is frequently present in an individual case. Individual risk factors may be potentiated by travel-related factors and thus place certain passengers at higher risk.

\section{Biochemical Factors: Patient-Related Biochemical}

VTE Risk Factors for Hypercoagulability

These include: thrombophilia; activated protein $\mathrm{C}$ resistance, inherited (factor V Leiden); prothrombin gene mutation (G20210A); antiphospholipid antibodies; protein $\mathrm{S}$ and protein $\mathrm{C}$ deficiencies, and methylene tetrahydrofolate reductase (MTHFR) polymorphism and hyperhomocystinemia MTHFR A1298C and C677T. The conditions have established association with VTE and have been recorded in individuals suffering from travel-related thromboses.

Thrombophilia. The role of thrombophilia in the pathogenesis of travel-related VTE was studied by Lord and McGrath [21] in 1993. Thrombophilia was identified in $72 \%$ of patients with travel-related VTE $[22,23]$. The major defects associated with familial thrombophilia are: activated protein $\mathrm{C}$ resistance caused by Arg 506 to Gln mutation (factor $\mathrm{V}$ Leiden), prothrombin polymorphism (G20210A) causing an elevated prothrombin level, hyperhomocystinemia, protein $\mathrm{C}$ deficiency, protein $\mathrm{S}$ deficiency, antithrombin deficiency and elevated factor VIII levels.

Activated Protein C Resistance. Activated protein C resistance, detected in $47 \%$ of the patients with travelrelated VTE [22-24], was the most common thrombophilic abnormality. About $34 \%$ of all patients showed a mutation in factor $V$ gene leading to $\mathrm{G} \rightarrow$ A substitution at the nucleotide position 1691. As a result of this substitution of glutamine for arginine at amino acid position 506 (FV R506Q), the factor V becomes resistant to proteolytic downregulation by activated protein C (30\% heterozygous and $4 \%$ homozygous) [23]. Activated protein C resistance without factor $\mathrm{V}$ Leiden mutation is a risk factor for VTE [25] and was observed in $15 \%$ of the patients with travel-related VTE [23]. Rees et al. [26] analyzed 3,380 chromosomes (1,690 unrelated individuals) from 24 populations for the presence of factor V Leiden. The allele frequency was reported to be $4.4 \%$ in Europe, with the highest prevalence in Greeks (7\%) and $0.6 \%$ in Asia Minor. Factor V Leiden mutations were not found in any of the chromosomes from Africa, South East Asia, Australasia and America [26]. Dzimiri and Meyer [27] did not concur with the report by Rees et al. [26] and reported the distribution of factor V Leiden in Saudi Arabia (5 hetero/200, 2.5\%). They screened 200 unrelated healthy Saudi young men visiting the blood donor clinic at King Faisal Specialist Hospital and Research Center in Riyadh, Saudi Arabia. Five (2.5\%) of 200 individuals had the A $\rightarrow$ $\mathrm{G}$ mutation at position 1691 detected by $\mathrm{Mn} / 1$ digestion confirmed by direct sequencing [27]. Dahlbach [28] reported the frequency in the range of 3-7\%.

Prothrombin G20210 Gene Polymorphism. First reported by Poort et al. [29] in 1996, replacement of G by A at nt 20210 in the 3'-untranslated region of the prothrombin gene increases translation without altering the transcription of the gene, resulting in the elevated synthesis and secretion of prothrombin by the liver. This increased synthesis and secretion of prothrombin contributes to increased thrombotic risk by causing increased thrombin 
generation that can activate thrombin activatable fibrinolytic inhibitor resulting in fibrinolytic deficit. The A20210 allele is present in 5-7\% of VTE patients and is the second most common genetic risk factor for VTE [29-31]. A combined mutation of factor $\mathrm{V}$ Leiden and prothrombin gene 20210 is associated with a higher risk of VTE [3238]. In a travel-related VTE study, $24 \%$ of patients were heterozygotes for this mutation [23], $11 \%$ also had a factor V Leiden mutation, $2 \%$ had associated protein $\mathrm{S}$ deficiency and $36 \%$ of the premenopausal women on oral contraceptive agents showed this mutation.

Antiphospholipid Antibodies. Antiphospholipid antibody syndrome is an acquired disorder characterized by thrombotic manifestations together with laboratory evidence of autoantibodies. These antibodies recognize anionic phospholipid-protein complexes, and are found in $1-5 \%$ of the general population and in $50 \%$ of patients older than 80 years $[36,37]$ of which about $30 \%$ of the patients were reported to have thrombosis [38, 39]. Antiphospholipid antibodies were found in $15-20 \%$ of all VTE cases. Among the travel-related VTE events $8 \%$ of patients had antiphospholipid antibodies, 2\% lupus anticoagulants and $6 \%$ anticardiolipin antibodies.

Protein $S$ and Protein C Deficiencies. Protein $\mathrm{S}$ is a vitamin K-dependent glycoprotein, synthesized by hepatocytes, neuroblastoma cells, kidney cells, testis, megakaryocytes, and endothelial cells. It is found in $\alpha$-granules of platelets and is a nonenzymatic cofactor of activated protein $\mathrm{C}$ in the inactivation of Va and VIIIa [40-45]. Inherited in an autosomal dominant manner, protein $\mathrm{S}$ deficiency accounts for only $1 \%$ of thrombotic events and $7 \%$ among patients with travel-related VTE [22, 23]. Patients with protein $\mathrm{S}$ deficiency may also be predisposed to arterial thrombosis [46]. Protein C, a zymogen, synthesized in liver, is a vitamin K-dependent inhibitor of factors Va and VIIIa. Hereditary protein $\mathrm{C}$ deficiency, an autosomal dominant disorder, is associated with a 7-fold increased risk of VTE $[47,48]$. Among patients with travel-related VTE, $4.8 \%$ of patients had deficiency of protein $\mathrm{C}$ [23]. Protein $\mathrm{C}$ and $\mathrm{S}$ levels are reduced by vitamin K deficiency, anticoagulation with warfarin and liver failure [49]. The levels of protein S are altered by age, oral contraceptives and pregnancy and are falsely low in the presence of factor V Leiden [49].

Methylene Tetrahydrofolate Reductase (MTHFR) Polymorphism and Hyperhomocystinemia. Hyperhomocystinemia is commonly associated with VTE and arterial thrombosis. In a travel-related VTE study, 44\% (18\% homozygous and $26 \%$ heterozygous) showed a mutation in the MTHFR gene. Heterozygosity was not considered a risk factor for VTE [22]. The most common known genetic cause of hyperhomocystinemia involves polymorphism of the MTHFR gene, ntC677T and A1298C. MTHFR catalyzes the reduction of methylene tetrahydrofolate to methyl tetrahydrofolate with folate acting as a cofactor. Methyl tetrahydrofolate is important in the remethylation pathway of homocysteine where dietary folate and vita$\min B_{12}$ are also required. Acquired hyperhomocystinemia may be due to chronic renal failure, $\mathrm{B}_{12}, \mathrm{~B}_{6}$ and folate deficiency states or may be induced by cyclosporine and methotrexate treatment.

Combined Genetic Defects. Deda et al. [50] reported on combined genetic defects of protein $\mathrm{S}$ deficiency, factor $\mathrm{V}$ Leiden mutation and a high level of factor VIII in a 10year-old Turkish boy with ischemic stroke.

\section{Physical Factors Associated with VTE Risks for Individuals}

Age. The risk of VTE increases with age and the incidence is 1 in 100 for patients over the age of 75 years [51].

Weight and Height. Obesity has an association with the development of postoperative VTE and in a study with travel-related VTE [52], 58\% of patients were considered overweight [21, 22]. Spontaneous DVT has been reported in the legs of tall men and it is postulated that the greater vein length may increase the difficulty of venous return to the vena cava thus predisposing an individual to stasis and thrombosis [53].

\section{Other Factors Associated with VTE Risks for}

\section{Individuals}

Oral Contraceptives. Oral contraceptives increase the risk of VTE [54]. In a travel-related VTE study, $73 \%$ of the premenopausal women and $53 \%$ of the postmenopausal women were taking oral contraceptives [23]. Government of UK guidelines state that people with a history of thrombosis and who have been taking hormone replacement therapy are among those at greater risk of suffering from DVT.

Additional Risk Factors. A medical history including previous DVT or pulmonary embolism, recent surgery or malignancy correlates with increased risk of VTE.

\section{In-Flight Factors and VTE Risks}

The particular environment to which passengers are exposed during long-haul air travel may potentiate individual risk factors for development of DVT. 


\section{Venous Stasis}

Immobility, regardless of cause, results in decreased venous return and stasis. When blood flow becomes sluggish and tends to stagnate, venous thrombi are formed in the valve pockets. Venous stasis is itself a principal precipitating factor for DVT [55]. Advanced age and immobilization further increase the frequency of thrombosis. Venous stasis is associated with impaired fibrinolysis and activation of coagulation [56, 57], increased fluid retention, causing swelling in the legs [58] and increased erythropoietin levels [59].

\section{Physiological Stress}

Dehydration and Hemoconcentration Resulting from Reduced Humidity. A fall in cabin relative humidity $(\mathrm{RH})$ from 47 to $11 \%$ occurs within 30 min of takeoff [60]. This low RH may contribute to excessive fluid loss, hemoconcentration and dehydration. Decreased urine output with an increased osmolality and the resulting hemoconcentration contributes to VTE [61]. Simons and Krol [62] demonstrated the increase in mean plasma and urine osmolality of patients exposed to simulated flight at an altitude of 8,000 feet and $8-10 \% \mathrm{RH}$.

Hypoxia and Altitude. Most commercial aircraft reach an altitude of 26,000-42,000 feet (50,000-60,000 feet for Concorde), at which altitude the atmospheric pressure, which was $760 \mathrm{~mm} \mathrm{Hg}$ at ground level, decreases to $176 \mathrm{~mm} \mathrm{Hg}$. Since it is impossible to maintain the cabin pressure at a value equivalent to ground level, aircraft are pressurized so that the cabin pressure is maintained at the equivalent of around 5,000-8,000 feet altitude regardless of the cruising altitude [62]. The arterial oxygen pressure (98 $\mathrm{mm} \mathrm{Hg}$ at sea level) falls with increasing altitude [63, 64]. Simulated flight experiments performed in hypobaric chambers with an inside ambient pressure of $75.8 \mathrm{kPa}$ (equivalent to cabin altitude of 8,000 feet) showed that the alveolar $\mathrm{pO}_{2}$ drops to only $59 \mathrm{~mm} \mathrm{Hg}$ and mean oxygen saturation reaches $90 \%$ after 30 min of exposure [65, 66]. Passengers may experience relative hypoxia, especially during takeoff and if the passengers have preexisting respiratory or cardiac problems, this change would be troublesome. Hypoxia can cause activation of coagulation and enhanced expression of plasminogen activator inhibitor 1 , thereby suppressing fibrinolysis [11, 12, 67]. Shortterm exposure to high altitude causes coagulation activation and inhibition of fibrinolysis [68]. Bendz et al. [69] demonstrated association between acute hypobaric hypoxia and activation of coagulation in humans [70, 71]. It was also reported that low molecular weight heparins prevent activation of coagulation in a hypobaric chamber
[72]. It would be interesting to observe if there is any enhanced expression of thrombin activatable fibrinolytic inhibitor. Hypoxia may also cause endothelial activation and injury. Release of endothelium-derived relaxing factor can cause relaxation of venous walls resulting in venous stasis [12]. Effects of sleep can influence hypoxia. Lower oxygen saturations of $80 \%$ at cabin altitudes of 8,000 feet were observed in individuals who were sleeping during a flight [62]. Drowsiness, immobility, cramped conditions, and low cabin pressure leading to distension of the abdomen can limit the normal movements of the diaphragm. Once the passenger breathes normally, the oxygen saturation level increased [62]. Hypoxemia also leads to vasodilatation; increased capillary permeability in combination with immobility results in edema.

\section{Other Factors}

Radiation Exposure. During flights the pilots, cabin crew and passengers are exposed to increased levels of cosmic radiation which primarily consists of neutrons and gamma rays. Higher levels are experienced at the highest altitudes and in the polar regions [73]. A direct link between cosmic radiation and thrombosis has so far not been established.

Related Conditions: Air Travel and Risk of Arterial Thrombosis. Current reports on flying and thrombosis mainly refer to venous thromboembolic complications. However, individuals with arterial diseases are also predisposed to symptomatic problems after extended air travel. Stress, and blood flow alterations contribute to ischemic events. Therefore, individuals with diabetic arteriopathy, advanced atherosclerosis and microangiopathic disorders are predisposed to complications. Although a systematic study on the prevalence of arterial thrombosis is not available, the reported incidence of acute coronary syndrome and myocardial infarction points in this direction. It is for this reason that some airlines have outfitted aircraft with defibrillators.

\section{Solutions: Approaches to Reducing Risks of Travel-Related Thrombosis}

Reduction of VTE risks for the traveling public must involve both individual action by passengers and the provision of good travel conditions by the airline carriers. All aspects of airline safety are subject to strict control and regulation by governmental agencies and international authorities and organizations. 


\section{Individual Action to Reduce VTE Risk}

\section{Behavior Modifications}

Mobility and Exercise. Passengers are usually advised to move about and exercise especially during long flights in order to improve circulation [74, 75]. Passengers should heed this advice. However, if passengers do not get any opportunity to move about due to turbulence, they may remain seated and perform dorsiflexion of the feet to improve circulation. Wright and Osborn [76] have shown that venous velocity was doubled after vigorous dorsivolar flexion of the foot. Sochart and Hardinger [77] have recently demonstrated that all passive or active movements (ankle dorsiflexion and plantar flexion, subtalar inversion and eversion and a combination) resulted in an increase in mean and peak blood velocities in common femoral veins. Mechanical devices to enhance foot and leg movements by passengers while seated have been developed.

Fluid Balance. Passengers should drink plenty of fluids and avoid alcohol or diuretics, unless medically advised.

\section{Prophylaxis}

\section{Pharmacological Prophylaxis}

Low molecular weight heparins (LMWHs), antiplatelet agents and warfarin are generally used for the prophylaxis of VTE. LMWHs have several advantages when compared to unfractionated heparin, including higher bioavailability, longer half-life and no need for laboratory monitoring. LMWHs have been shown to be effective for the prevention of VTE in high-risk patients who undergo hip or knee surgery or in patients with major trauma or acute spinal cord injury [78]. Antiplatelet drugs were found to have much less protective effect than anticoagulant agents [79]. The use of aspirin to prevent VTE is controversial and hence is not recommended [17].

\section{Mechanical Prophylaxis}

Graduated Compression Stockings. These stockings increase the venous blood flow velocity. In two separate meta-analyses, 9.3 and $11.2 \%$ of postoperative patients experienced DVT when compared to 24.5 and $27 \%$ in the placebo groups, respectively [80, 81]. Marshall and Dormandy [82] found a 60-ml increase in lower limb volume during a flight from Frankfurt to Kyoto, when no preventive measures were undertaken. In one study, Lowe et al. [83] demonstrated the efficacy of $25-32 \mathrm{~mm} \mathrm{Hg}$ graduated-compression stockings for prevention of venous edema during a 14.4-hour night flight. In a recent study (LONFLIT 2), Belcaro et al. [16] enrolled 833 subjects, 422 randomized as control subjects and 411 used belowknee stockings. After an average flight duration of $12.4 \mathrm{~h}$, $4.5 \%$ of the control subjects and only $0.24 \%$ of the subjects using below-knee stockings developed DVT (thrombosis detection based on ultrasound scans), showing a statistically significant difference. Thus, it was observed that subjects wearing stockings had 18.75 times lower incidence of DVT compared to the controls. It was concluded that long-haul flights were associated with DVT in $4.5 \%$ of the high-risk patients and that below-knee stockings were beneficial in reducing the incidence of DVT [16]. Battery-driven intermittent compression pumps that can give foot or calf compression during the flight have also been developed.

\section{Approaches by Organizations to Combat Travel-Related VTE}

\section{Airlines}

Airlines should consider providing passengers with information related to long-distance flight and its association with development of VTE together with a description of the preventive measures that can be taken in order to minimize risk. This information could be provided on a card similar to the one provided for aircraft safety information. If this information is also given at the time of purchase of the tickets, or at least before the flight, the passengers could have enough time to discuss this matter with their physicians and receive additional safety tips. Passengers with severe individual risk factors, such as previous DVT or recent surgery, could then arrange for specific prophylaxis under medical direction. Airlines should also work to make available more leg space and thus facilitate leg mobility for passengers during long-haul flights. Passengers should be encouraged to move out of their seats and either exercise or at least walk a few steps, whenever it is safe to do so. Passengers should be encouraged by cabin staff to drink plenty of fluids during the flight and to avoid alcohol.

\section{Governments and Regulatory Authorities}

The WHO in collaboration with ICAO and IATA are planning large prospective studies to further establish the importance of travel and travel-related conditions in the development of venous thromboembolic complications. Clinical trials and databases to record the incidence of thrombosis in patient groups with both arterial and ve- 
nous thrombosis may be helpful. Investigation of improved laboratory methods to predetermine the risk profile of travelers may be of general utility. An optimum interseat distance should be established in order to facilitate adequate leg mobility for passengers.

\section{Conclusions}

Public and professional understanding of travel-related venous thromboembolic complications and close interactions of physicians, health care authorities and national and international aviation authorities would help to provide safer long-distance air travel.

\section{References}

1 Silverstein MD, Heit JA, Mohr DN, Petterson TM, O'Fallon WM, Melton LJ: Trends in the incidence of deep vein thrombosis and pulmonary embolism: A 25-year population-based study. Arch Intern Med 1998;158:585-593.

2 Rosendaal FR: Venous thrombosis: A multicausal disease. Lancet 1999;353:1167-1173.

3 Virchow R: Gesammelte Abhandlungen zur wissenschaftlichen Medicine. Frankfurt, Meidinger, 1856.

4 Homans J: Thrombosis of the deep leg veins due to prolonged sitting. N Engl J Med 1954; 250:148-149.

5 Symington IS, Stack BHR: Pulmonary thromboembolism after travel. Br J Chest 1977;71: 138-140.

6 Sarvesaran R: Sudden natural deaths associated with commercial air travel. Med Sci Law 1986;26:35-38.

7 Arfvidsson B, Ecklof B, Kistner R, Ogawa T, Parsi K: A prospective evaluation of the risk for venous leg thrombosis associated with prolonged air travel: A pilot study. Hawaii Med J 2000;59:167-168.

8 Arfvidsson B, Eklof B, Kistner RL, Masuda EM, Sato DT: Risk factors for venous thromboembolism following prolonged air travel: Coach class thrombosis. Hematol Oncol Clin North Am 2000;14:391-400.

9 Ferrari E, Chevallier T, Chapelier A, Badouhy M: Travel as risk factor for thromboembolic disease: A case control study. Chest 1999;115: 440-444.

10 Mercer A, Brown JD: Venous thromboembolism associated with air travel: A report of 33 patients. Aviat Space Environ Med 1998;69: 154-157.

11 Forbes CD, Johnston RV: Venous and arterial thrombosis in airline passengers (editorial). JR Soc Med 1998;91:565-566.

12 Satoh A, Daimaru O, Magaki K, Morishita M, Katoh H, Kawajiri T, Miyara H, Sakurai E, Tutui S, Oguri T: Pulmonary embolism that developed during an airplane flight: 'Economy class syndrome' (in Japanese). Nihon Kokyuki Gakkai Zasshi 1998;36:524-530.

13 Samama MM: An epidemiological study of risk factors for deep vein thrombosis in medical outpatients: The Sirius study. Arch Intern Med 2000;160:3415-3420.

14 Kraajenhagen RA, Harvekamp D, Koopman MM, Prandoni P, Piovella F, Buller HR: Travel and risk of venous thrombosis. Lancet 2000; 356:1492-1493.
15 Scurr JH, Machin SJ, Balley-King S, Machie IJ, McDonald S, Smith PD: Frequency and prevention of symptomless deep-vein thrombosis in long-haul flights: A randomized trial. Lancet 2001;357:1485-1489.

16 Belcaro G, Geroulakos G, Nicolaides AN, Myers KA, Winford M: Venous thromboembolism from air travel. The LONFLIT study. Angiology 2001;52:369-374.

17 Parsi K, McGrath MA, Lord RSA: Traveller's venous thromboembolism: A review of world literature, a survey of the world airlines and an Australian perspective. Aust NZ J Phlebol 2001;5:32-53.

18 Lapostolle F, Surget V, Barron SW, Desmaizieres M, Sordelet D, Lapandry C, Cupa M, Adnet F: Severe pulmonary embolism associated with air travel. N Engl J Med 2001;345:779_ 783.

19 Kline JA, Putman M, Courtney DM: Fatal pulmonary embolism immediately after transatlantic air travel to the United States: Less than one in a million (letter to the editor). Thromb Haemost 2002;87:342.

20 Eklof B: Voyages aériens et maladie veineuse thrombo-embolique: Rapport O.M.S. Angiologie 2001;53:11-14.

21 Lord RSA, McGrath M: Traveller's venous thrombosis; in Int Soc Cardiovasc Surg Meet, Lisbon, September 1993.

22 Parsi K, McGrath MA, Lord RSA: Traveller's venous thromboembolism. Hawaii Med J 2000;59:160-161.

23 Parsi K: Traveller's Venous Thromboembolism; Master of Science, Medicine, University of New South Wales, Sydney, 2001.

24 Emonson DL: Activated protein $\mathrm{C}$ resistance as a 'new' cause of deep venous thrombosis in aviators. Aviat Space Environ Med 1997;68: 606-608.

25 De Visser MCH, Rosendaal FR, Bertina RM: A reduced sensitivity for activated protein $\mathrm{C}$ in the absence of factor $\mathrm{V}$ Leiden increases the risk of venous thrombosis. Blood 1999;93: 1271-1276.

26 Rees DC, Cox M, Clegg JB: World distribution of factor V Leiden. Lancet 1995;346:11331134.

27 Dzimiri N, Meyer B: World distribution of factor V Leiden (letter). Lancet 1996;347:481482.

28 Dahlbach B: Molecular genetics of venous thromboembolism. Ann Med 1995;27:187192.
29 Poort SR, Rosendaal FR, Reitsma PH, Bertina RM: A common genetic variation in the 3'untranslated region of the prothrombin gene is associated with elevated plasma prothrombin levels and an increase in venous thrombosis. Blood 1996;88:3698-3703.

30 Hillarp A, Zoller B, Svenson PJ, Dahlback B The 20210 A allele of the prothrombin gene is a common risk factor among Swedish outpatients with verified deep venous thrombosis. Thromb Haemost 1997;78:990-992.

31 Rosendaal FR, Siscovick DS, Schwartz SM, Psaty BM, Raghunathan TE, Vos HL: A common prothrombin variant (20210 G to A) increases the risk of myocardial infarction in young women. Blood 1997;90:1747-1750.

32 Ferraresi P, Marchetti G, Legnani C, Cavallari E, Castoldi E, Mascoli F, Ardissino D, Palareti G, Bernardi F: The heterozygous 20210 G/A prothrombin genotype is associated with early venous thrombosis in inherited thrombophilias and is not increased in frequency in artery disease. Arterioscler Thromb Vasc Biol 1997; 17: 2418-2422.

33 Zoller B, Svensson PJ, Dahlback B, Hillarp A: The A 20210 allele of the prothrombin gene is frequently associated with the factor V Arg 506 to Gln mutation but not with protein $\mathrm{S}$ deficiency in thrombophilic families. Blood 1998; 91:2210-2211.

34 Ehrenforth S, Ludwig G, Klinke S, Krause M, Scharre I, Nowak-Gottl U: The prothrombin 20210A allele is frequently coinherited in young carriers of the factor B Arg 506 to Gln mutation with venous thrombophilia. Blood 1998;91:2209-2210.

35 Duncan A: The prothrombin gene 3'-untranslated region mutation is frequently associated with factor V Leiden in thrombophilic patients and shows ethnic specific variation in allele frequency. Blood 1998;91:1092.

36 Silver D, Vouyouka A: The caput medusae of hypercoagulability. J Vasc Surg 2000;31:396405.

37 Manoussakis MN, Tzioufas AG, Silis MP, Pange PJ, Goudevenous J, Moutsopoulos HM: High prevalence of anti-cardiolipin and other autoantibodies in a healthy elderly population. Clin Exp Immunol 1987;69:557-565.

38 Lechner K, Pabinger-Fasching I: Lupus anticoagulant and thrombosis: A study of 25 cases and review of the literature. Haemostasis 1985 ; $15: 254$. 
39 Gestinou DA, Kazmier FJ, Nichols WL, Bowie EJW: Lupus anticoagulant: An analysis of the clinical and laboratory features of 219 cases. Am J Hematol 1985; 19:265.

40 Phillips DJ, Greengard JS, Fernandez JA, Ribeiro M, Evatt BL, Griffin JH, Hooper WC Protein S, an antithrombotic factor, is synthesized and released by neural tumor cells. J Neurochem 1993;61:344-347.

41 Fair DS, Marlar RA: Biosynthesis and secretion of factor VII, protein C, protein S and protein $\mathrm{C}$ inhibitor from a human hepatoma cell line. Blood 1986;67:64.

42 Stern D, Brett J, Harris K, Nawroth P: Participation of endothelial cells in the protein C-protein $\mathrm{S}$ anticoagulant pathway: The synthesis and release of protein S. J Cell Biol 1986;102: 1971-1978.

43 Malm J, He XH, Bjartell A, Shen L, Abrahamsson PA, Dahlback B: Vitamin K-dependent protein $\mathrm{S}$ in Leydig cells of human testis. Biochem J 1994;302:845-850.

44 Fair DS, Marlar RA, Levin EG: Human endothelial cells synthesize protein S. Blood 1986; 67:1168-1171.

45 Schwartz HP, Heeb MJ, Wencel-Drake JD, Griffin JH: Identification and characterization of protein $\mathrm{S}$ in human platelets. Blood 1985;66: 1452.

46 Engesse L, Broekmans AW, Briet E, Brommer EJP, Bertina RM: Hereditary protein S deficiency: Clinical manifestations. Ann Intern Med 1987;106:677-682.

47 Koster T, Rosendaal F, Briet E, Van der Meer FJM, Colly LP, Trienekens PH, Poort SR, Vandenbrouke JP: Protein $\mathrm{C}$ deficiency in a controlled series of unselected outpatients: An infrequent but clear risk for venous thrombosis (Leiden Thrombophilia Study). Blood 1995;85: 2756-2761.

48 Allaart CF, Poort S, Rosendaal FR, Reitsma $\mathrm{PH}$, Bertina RM, Briet E: Increased risk of venous thrombosis in carriers of hereditary protein C deficiency. Lancet 1993;341:134138.

49 Presgrave P, Ma D: Genetic predisposition to venous thromboembolism: Molecular basis and a practical guide to management. Aust NZ J Phlebol 2000;4:39-45.

50 Deda G, Icagasioglu D, Caksen H, Akar N Combined genetic defects in a child with ischemic stroke: Case report. J Child Neurol 2002; 17:533-534.

51 Nordstrom M, Lindbald B, Bergquist D, Kjellstrom T: A prospective study of the incidence of deep vein thrombosis within a defined urban population. J Intern Med 1992;232:155-160.
52 Clayton JK, Anderson JA, McNocol GP: Preoperative prediction of postoperative deep vein thrombosis. BMJ 1976;ii:910-912.

53 Naide M: Spontaneous venous thrombosis in legs of all tall men. JAMA 1952;148:1202.

54 World Health Organization: Venous thromboembolic disease and combined oral contraceptives: Results of international multicenter case-control study. World Health Organization Collaborative Study of Cardiovascular Disease and Steroid Hormone Contraception. Lancet 1995;346:1575-1582.

55 Benoit R: La maladie thrombo-embolique du voyageur: Le syndrome de la classe économique. J Mal Vasc 1992;17(suppl B):84-87.

56 Gobin JP, Negrier C, Trzeciak MC, Dechavanne $\mathrm{M}$ : L'activation de la coagulation lors des voyages aériens: Est-elle un mythe ou une réalité? Artères Veines 1994;13:5-7.

57 Levy Y, George J, Shoenfeld Y: The occurrence of thromboembolic events following airplane flights: 'The economy class syndrome'. Isr J Med Sci 1995;31:621-623.

58 Paganin F, Laurent Y, Gauzere BA, Blanc P, Roblin X: Pulmonary embolism on non-stop flights between France and Réunion Island. Lancet 1996;347:1195-1196.

59 Marsepoil T, Godard S, Letessier G, Ghanem M, Laine R: Complications thrombo-emboliques des vols aériens de longue durée. Presse Méd 1991;20:383.

60 Eng WG, Harada LK, Jagerman LS: The wearing of hydrophilic contact lenses aboard a commercial jet aircraft: 1 . Humidity effects on fit. Aviat Space Environ Med 1982;53:235-238.

61 Druilhe L, Fornes P, Mercier JF, Lecomte D: Embolie pulmonaire et voyages aériens: Etude d'un cas et revue de la litérature. J Méd Lég Droit Médic 1994;37:429-434.

62 Simons R, Krol J: Jet lag, pulmonary embolism and hypoxia. Lancet 1996;348:416.

63 James PB: 'Jet lag', pulmonary embolism and hypoxia. Lancet 1996;347:1696.

64 Bagshaw M: Jet lag, pulmonary embolism and hypoxia. Lancet 1996;348:415-416.

65 Caprini J: Air travel-related venous thromboembolism: Chicago views. Hawaii Med J 2000; 59:156-158.

66 Harinck E, Hutter PA, Hoorntje TM, Simons $\mathrm{M}$, Benataar AA, Fischer JC, de Bruijn, D, Meijboom EJ: Air travel in adults with cyanotic congenital heart disease. Circulation 1996;93: 272-276.

67 Patel A, Fuchs GJ: Air travel and thromboembolic complications after percutaneous nephrolithotomy for staghorn stone. J Endocrinol 1998;12:51-53.

68 Manucci PM: Short-term exposure to high altitude causes coagulation activation and inhibition of fibrinolysis. Thromb Haemost 2002;87: 3423.
69 Bendz B, Rostrup M, Sevre K, Andersen TO, Sandset PM: Association between acute hypobaric hypoxia and activation of coagulation in human beings. Lancet 2000;356:1657-1658.

70 Bendz B, Sandset PM: Air travel and venous thrombosis. Tidsskr Nor Lægeforen 2002;122: 1579-1581.

71 Sevre K, Bendz B, Hanko E, Nakstad AR, Hauge A, Kasin JI, Lefrandt JD, Smith AJ, Eide I, Rostrup M: Reduced autonomic activity during stepwise exposure to high altitude. Acta Physiol Scand 2001;173:409-417.

72 Bendz B, Sevre K, Andersen TO, Sandset PM: Low molecular weight heparin prevents activation of coagulation in a hypobaric environment. Blood Coagul Fibrinolysis 2001;12:371374.

73 Boice JD Jr, Blettner M, Auvienen A: Epidemiologic studies of pilots and aircrew. Health Phys 2000;79:576-584.

74 Burki U: Lung embolism during and following long-distance flights ('economy class syndrome') (in German). Schweiz Med Wochenschr 1989;119:287-289.

75 Mayo Clinic: How to prevent blood clots when traveling: Reliable information for a healthier life 2000; in Mayo Clinic Health Oasis. Available from: URL: Http://www.mayohealth.org/ mayo/9702/htm/clots.htm. ed: The Mayo Clinic; 2000 (cited 23 December, 2000).

76 Wright HP, Osborn SB: Effects of posture on venous velocity: Measured with ${ }^{24} \mathrm{NaCl} . \mathrm{Br}$ Heart J 1952; 14:325-330.

77 Sochart DH, Hardinger K: The relationship of foot and ankle movements to venous return in the lower limb. J Bone Joint Surg Br 1999; 81B:700-704.

78 Weitz JL: Low-molecular weight heparin. N Engl J Med 1997;337:688

79 Bounameaux $H$ : Integrating pharmacologic and mechanical prophylaxis of venous thromboembolism. Thromb Haemost 1999;82:931937.

80 Clagett GP, Reisch JS: Prevention of venous thromboembolism in general surgical patients: Results of a meta-analysis. Ann Surg 1988;208: 227-240.

81 Colditz GA, Tuden RL, Oster G: Rates of venous thrombosis after surgery: Combined results of randomized clinical trials. Lancet 1986; ii:143-146.

82 Marshall M, Dormandy JA: Oedema of long distance flights. Phlebology 1987;2:123-124.

83 Lowe D, Gerlach HE, Altenkamper KH, Schneider B: Effects of long distance flights on oedema of the lower extremities. Phlebology 1998;13:64-67. 